\title{
DESAIN DIDAKTIS MATEMATIS PROBLEM SOLVING PADA KONSEP KESEBANGUNAN
}

\section{(MATHEMATICAL DIDACTIC DESIGN OF PROBLEM SOLVING ON CONVERGENCE)}

\author{
Ahmad Firdaus ${ }^{1}$, Anwar Mutaqin ${ }^{2}$ \\ ${ }^{1}$ Program Studi Pendidikan Matematika, Universitas Sultan Ageng Tirtayasa, \\ ahmadfirdaus1005@gmail.com \\ ${ }^{2}$ Program Studi Pendidikan Matematika, Universitas Sultan Ageng Tirtayasa, \\ anwarmutaqin@gmail.com
}

\begin{abstract}
Abstrak
Survei yang dilakukan pada tahun 2009 oleh Organisation for Economic Cooperation and Development (OECD) pada tes PISA menunjukkan bahwa Indonesia mendapatkan pringkat ke 61 dari 65 negara partisipan. Salah satu penyebab mutu pendidikan matematika Indonesia yang rendah adalah kurangnya bahan ajar dengan pendekatan problem solving, sehingga kemampuan pemecahan masalah siswa kalah bersaing di kancah internasional. Penelitian pengembangan ini dilakukan dalam rangka menghasilkan bahan ajar interaktif berbasis komputer berupa $p d f$. Bahan ajar dibuat berdasarkan repersonalisasi terhadap learning obstacle yang teridentifikasi melalui instrument untuk mereduksi learning obstacle yang teridentifikasi. Penelitian ini menggunakan metode penelitian desain didaktis (Didactical Design Research) yang terdiri dari tiga tahap: analisis situasi didaktis termasuk antisispasi didaktis pedagogis, analisis metapedadidaktis, dan retrofektif yang mengaitkkan hasil analisis situasi didaktis hipotesis dengan hasil analisis metapedadiaktis. Terdapat empat tipe learning obstacle yang teridentifikasi sebelum bahan ajar dibuat, dan selanjutnya bahan ajar dilakukan validasi oleh beberapa ahli yaitu: ahli matematika dan ahli pendidikan. Sedangkan untuk implementasi desain didaktis dilakukan kepada 37 siswa kelas IX SMP N 7 kota Serang. Hasil implementasi desain didaktis menunjukkan tingkat kognitif siswa sebesar 0.83 serta mereduksi learning obstacle yang teridentifikasi.
\end{abstract}

Kata kunci: Learning Obstacle, Desain Didaktis, Kesebangunan.

\begin{abstract}
The survey conducted in 2009 by Organisation for Economic Cooperation and Development (OECD) on PISA test pointed that Indonesia place on $61^{\text {th }}$ grade of 65 countries in which participated. One of the low-grade education factors in Indonesia is lack of teaching materials with problem solving approaches, so that students' problem solving abilities are unable to compete internationally. This development research was carried out in order to produce computer-based interactive teaching materials in the form of pdf. Teaching materials are constructed based on personalization of the learning obstacle identified through an instrument to reduce the identified obstacle learning. This research uses Didactic Design Research methods which
\end{abstract}


consists of three stages: didactic situation analysis including didactic pedagogical antispation, analysis of metapedadictis, and retrofective which link the results of didactic situation analysis of hypotheses and the results of metapedadiactic analysis. There are four types of obstacle learning that are identified before the teaching material is made, and then the teaching materials are validated by several experts : Mathematician and education experts. for the implementation of the didactic design carried out for 37 students of Class IX SMP N 7 in Serang City. The results of the didactic design implementation showed the cognitive level of students was 0.83 and reduced the learning obstacle identified.

Keywords: Learning Obstacle, Didactic Design, Convergence

\section{PENDAHULUAN}

Hasil survei yang dilakukan oleh Organisation for Economic Co-operation and Development (OECD) pada tes PISA. Skor kemampuan matematika siswa Indonesia pada tahun 2009 skor Indonesia 371 dari sekor rata internasional 500 dan Indonesia mendapatkan pringkat ke 61 dari 65 negara partisipan. Kompetensi matematis yang tergolong rendah ini disebabkan siswa tidak terbiasa menyelesaikan soal-soal pemecahan masalah seperti soal-soal yang terdapat pada tes PISA. Kemampuan dalam memecahkan masalah matematis tidak akan tercipta tanpa adanya pembelajaran yang bermakna, oleh karena itu pembelajar problem solving merupakan salah satu cara efektif pembelajaran bermakna. Salah satu tujuan dari pembelajaran matematika sekolah menurut pendapat Muhson (dalam Irawan, 2011:3) bahwa problem solving dalam pembelajaran dapat meningkatkan pemahaman siswa, penguasaan materi dan minat belajar siswa.

Untuk mencapai kemampuan pemecahan masalah matematis dalam pembelajaran problem solving di kelas tidak mudah, karena dalam prosesnya akan menemukan hambatan-hambatan belajar (Learning Obstacle). Menurut Suratno (dalam Agustina, 2012: 8) bahwa pada praktiknya, siswa secara alamiah mengelami situasi yang disebut kesulitan belajar yang dikenal dengan learning obstacle. Ada tiga macam kesulitan belajar yang dialami siswa yaitu Ontogeni, Didaktis, dan Epistimologi, dari ketiga macam hambatan tersebut ada dua macam hambatan yang dapat diberikan perlakuan untuk mengurangi hambatan belajar yaitu Didaktis dan Epistimologi.

Adapun hambatan Didaktis adalah hambatan yang akan terjadi ketika persiapan pembelajaran yang direncanakan oleh guru tidak optimal, sehingga guru tidak fokus mengarahkan siswa dalam pembelajaran problem solving. Sedangkan hambatan Epistimologi adalah keterbatasan kemampuan siswa pada konteks tertentu, contohnya ketika siswa diminta untuk menjawab soal rutin maka siswa dengan mudah menemukan solusinya secara langsung akan tetapi ketika soal rutin tersebut dimodifikasi menjadi bentuk soal non-rutin, siswa tidak dapat menjawab soal tersebut maka dapat dikatakan siswa tersebut mengalami hambatan Epistemologi.

Oleh karena itu guru perlu mengambil tindakan secara khusus untuk mengatasi hambatan yang dialami oleh siswa dalam pembelajaran. Perhatian yang diberikan khususnya pada hubungan antara siswa dan materi karean hubungan tersebut dapat menciptakan situasi Didaktis yang kondusif dalam membentuk pola berpikir matematis pada siswa. Menurut Suryadi (2010: 5) "terdapat dua hal 
mendasar yang perlu pengkajian serta penelitian lebih lanjut dan mendalam tentang pengembangan berpikir matematis tingkat tinggi melalui pendekatan tidak langsung yaitu hubungan siswa-materi dan guru-siswa". Dalam hubungan tersebut perlu adanya dorongan untuk terjadinya aksi mental, maka dalam pembelajaran perlu disajikan masalah matematis agar terjadinya proses berpikir. Jika aksi mental yang diharapkan tidak terjadi, yakni ditandai oleh ketidakmampuan siswa dalam menjelaskan keterkaitan antar objek mental yang berhubungan dengan masalah yang dihadapi, maka guru dapat melakukan tindakan intervensi tidak langsung melalui penerapan tindakan scaffolding (tindakan didaktis).

Tindakan didaktis yang perlu dilakukan terhadap hubungan antara siswa dengan materi dan siswa dengan guru melalui pendekatan tidak langsung dapat berupa pembuatan bahan ajar yang didasarkan pada learning obstacle siswa dengan pendekatan problem solving. Tindakan tersebut lebih efektif dibandingkan dengan mengganti metode pembelajaran yang dilakukan guru di kelas. Sehingga dengan melakukan tindakan Didaktis tersebut yakni pembuatan bahan ajar dengan pendekatan problem solving maka diharapkan guru yang memiliki kecenderungan menggunakan metode konvensional akan beralih pada pembelajaran problem solving berdasarkan learning obstacle.

Berdasarkan uraian di atas maka peneliti ingin melakukan penelitian terkait bahan ajar yang didasarkan pada learning obstacle pada siswa, penelitian ini dilakukan guna mengetahui tindakan Didaktis yang tepat dalam mengatasi learning obstacle pada siswa. Oleh karena itu dalam penelitian ini peneliti memberi judul "Desain Didaktis Matematis Problem Solving pada Konsep Kesebangunan".

\section{KAJIAN TEORI}

Pada hakekatnya untuk memahami materi matematika serta menyelesaikan masalah matematis dalam pembelajaran matematika siswa memerlukan konsentrasi yang cukup tinggi. Akan tetapi pada proses pemebelajaran matematika tidak mudah bagi siswa untuk mencapai konsentrasi tersebut, karena akan selalu ada hambatan dalam pembelajaran matematika. Menurut Sulistiawati (2012:18) "ada 3 jenis learning obstacle, yaitu ontogenical learning obstacle, didactical learning obstacle dan epistemological learning obstacle."

Hambatan Ontogeni adalah hambatan belajar yang disebabkan oleh kesiapan mental siswa dalam menghadapi proses pembelajaran dimana kesulitan belajar yang dialami siswa dikarenakan siswa belum mempelajari materi tersebut. Hambatan Didaktis yaitu hambatan yang disebabkan oleh pengajaran guru. Maksud dari hambatan pengajaran guru ini adalah bagaimana persiapan guru dalam melakukan pemebelajaran di kelas yang belum baik dan kurang optimal sehingga berdampak kepada pemahaman siswa tetang materi yang diajarkan. Sedangkan hambatan Epistemologi adalah hambatan yang disebabkan oleh keterbatasan pengetahuan siswa dalam bidang tertentu.

Menurut Kansanen (dalam Suryadi, 2010:62) ada dua aspek mendasar dalam proses pembelajaran matematika yaitu hubungan siswa-materi dan hubungan guru-siswa, ternyata dapat menciptakan suatu situasi didaktis maupun pedagogis yang tidak sederhana bahkan seringkali sangat kompleks, hubungan antar siswa dan materi disebut dengan hubungan didaktis (HD) serta hubungan guru dan siswa disebut hubungan pedagogis (HP). Menurut Suryadi (2010:10) "hubungan didaktis dan pedagogis tidak bisa dipandang secara parsial akan tetapi 
harus dipahami secara utuh karena pada kenyataannya hubungan tersebut dapat terjadi secara bersamaan". Menyadari bahwa situasi didaktis dan pedagogis yang terjadi dalam pembelajaran begitu kompleks, maka kemampuan guru yang harus dikuasai selanjutnya akan disebut sebagai metapedadidaktis. Berdasarkan uraian di atas yang menggambarkan situasi didaktis dan pedagogis maka diperlukan tindakan yang dapat menghubungkan tiga komponen dalam pembelajaran yaitu hubungan antara guru, siswa, dan materi. Salah satu tindakan tersebut adalah pengembangan bahan ajar yang didasarkan pada analisis kesulitan belajar siswa (learning obstacle) dan respons siswa yang akan terjadi dalam pembelajaran, sehingga dapat menjebatani hubungan antara guru, siswa, dan materi. Hal ini senada dengan apa yang di paparkan bahwa bahan ajar menurut Asep, dkk. (2012: 3) merupakan instrument yang terdiri dari materi atau substansi pelajaran dimana penyusunannya "secara runtut dan sistematis"

Menurut Hoesana (2012:2) pemecahan masalah matematika dapat diartikan sebagai "suatu proses berpikir yang menggunakan pengetahuan matematika dalam menghadapi suatu permasalah untuk mencari jalan keluar atau mencari solusi dari kesulitan yang ada". Menurut Wardhani (2008:18) siswa dikatakan mampu memecahkan masalah bila ia memiliki kemampuan "memahami masalah, merancang model matematika, menyelesaikan model matematika, dan menafsirkan solusi yang diperoleh". Menurut Gagne (Tim MKPBM UPI, 2001: 36) dalam pemecahkan masalah biasanya ada lima langkah yang harus dilakukan yaitu: Menyajikan masalah dalam bentuk jelas, Menyatakan masalah dalam bentuk lebih operasional, Menyusun hipotesis-hipotesis alternatiF dan prosedur kerja yang diperkirakan baik, Mengetes hipotesis dan melakukan kerja untuk memperoleh hasilnya, Mengecek kembali hasil yang sudah diperoleh. Polya (Hoesana. 2012: 3) terdapat empat langkah dalam menyelesaikan masalah matematika yaitu: Pahami masalah, Rancang suatu strategi, Laksanakan strategi, Tinjau kembali dan kembangkan.

\section{METODE PENELITIAN}

Dalam penelitian ini, metode yang digunakan adalah Penelitian Desain Didaktis (Didactical Design Research) dengan pendekatan kualitatif melalui tiga tahapan analisis, Suryadi (2010:12) yaitu analisis situasi didaktis sebelum pembelajaran yang wujudnya berupa Desain Didaktis Hipotesis termasuk ADP. Analisis metapedadidaktik. Analisis retrosfektif yakni analisis yang mengaitkan hasil analisis situasi didaktis hipotesis dengan hasil analisis metapedadidaktik.

Adapun langkah-langkah yang digunakan mulai dari awal penelitian sampai pelaporan penelitian yaitu mengidentifikasi learning obstacle siswa dan karakteristik siswa. Merepersonalisasi dan menghasilkan desain Didaktis baru (dalam bentuk bahan ajar). Memprediksi respon siswa dibuat pada rencana pembelajarana yang akan dilakukan. Mengimplemantasi di kelas, yaitu pembelajaran menggunakan desain didaktis yang baru. Pada tahap ini, dilakukan identifikasi learning obstacle dan analisis metapedadidaktik. Analisis metapedadidaktik adalah upaya menganalisis hubungan antara siswa dan bahan ajar (hubungan didaktis), dan hubungan antara guru dengan siswa (hubungan pedagogis), dan prediksi respon siswa terhadap materi (antisipasi didaktis dan pedagogis), Dari hasil analisis metapedidaktf tersebut dan analisis retrospektif 
digunakan untuk merevisi desain didaktis yang baru. Pembuatan laporan penelitian

Berikut merupakan gambaran alur penelitian:

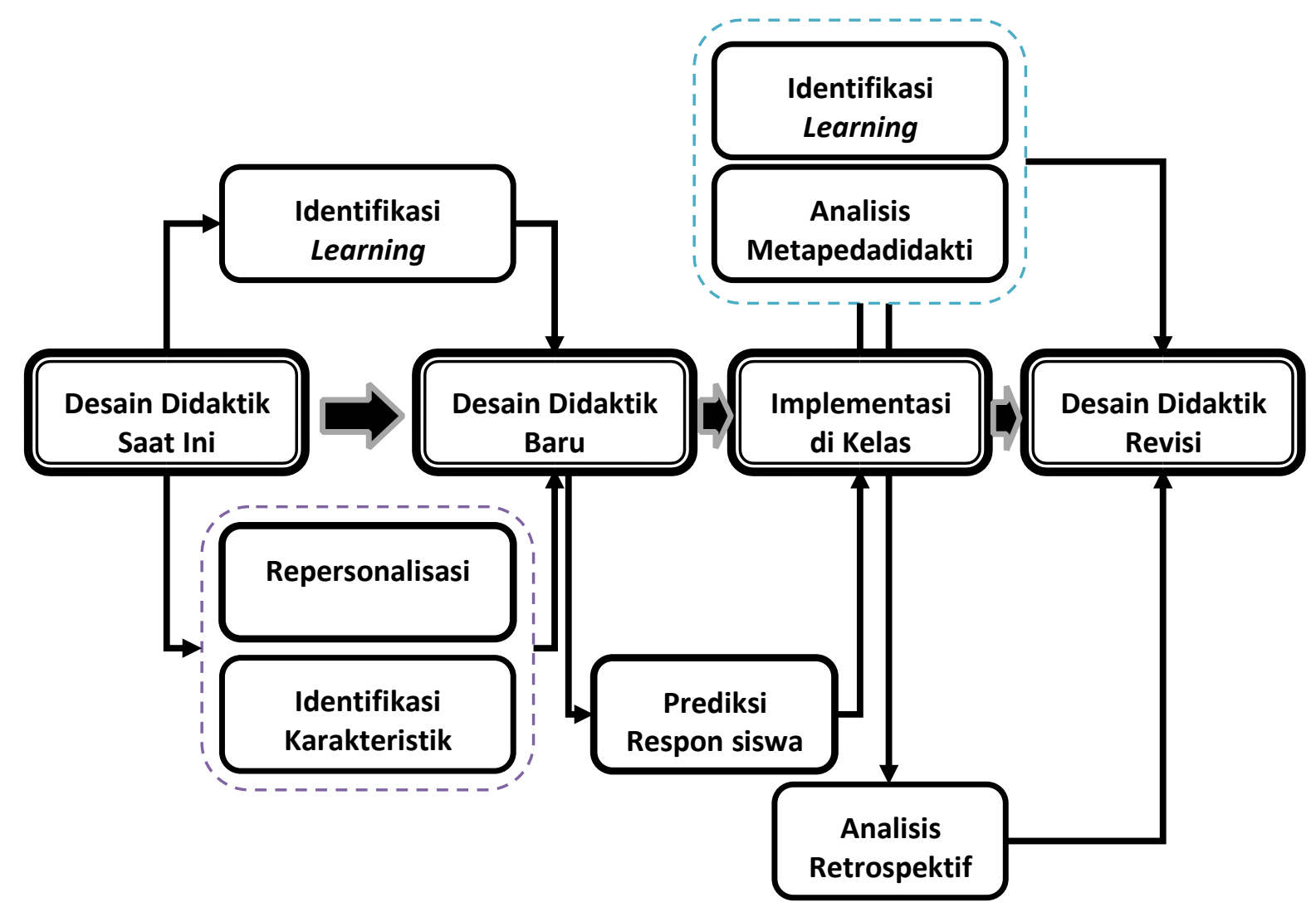

Gambar 1. Alur Penelitian Disain Didaktis Riset

\section{HASIL DAN PEMBAHASAN}

\section{Learning obstacle siswa pada konsep kesebangunan}

Untuk mengetahui Learning obstacle yang dialami siswa, akan dilakukan terlebih dahulu uji instrument berupa tes kemampuan responden (TKR) kepada siswa Kelas X SMA N 1 Pontang sebanyak 10 siswa. Berdasarkan hasil analisis jawaban siswa dan wawancara siswa dari berbagai learning obstacle tiap-tiap soal tersebut, maka secara umum learning obstacle yang dialami siswa pada konsep kesebangunan dapat dibagi menjadi 4 tipe, yaitu:
a. Tipe 1: Siswa tidak bisa membuat sketsa dan memanipulasi sketsa dengan benar.
b. Tipe 2: Siswa tidak dapat menentukan data yang diperlukan dalam menjawab soal.
c. Tipe 3: Siswa tidak dapat menentukan sisi-sisi yang bersesuaian pada objek yang sebangun dan kongruen.
d. Tipe 4: Siswa tidak dapat mengkonfersi soal cerita kepada konsep kesebangunan yang akan diselesaikan. 


\section{Desain Didaktis}

Pada proses pembuatan desain didaktis peneliti menggunaan Microsoft word 2010 untuk melakukan eksport file kedalam bentuk $p d f$. Seteah berhasil mengubah file kebentuk pdf, maka selanjutnya memasukan animasi, ilustrasi, audio-viusal dengan menggunakan Adobe Acrobat 9 Pro. Berikut adalah gambaran umum desain didaktis matematis problem solving pada konsep kesebangunan:

1. Format file : $p d f$

2. Ukuran file : $22 \mathrm{MB}$

3. Jenis huruf : Calibri, Time New Roman, dan Arnold 2.1

4. Materi : Kesebangunan

5. Software: Macromedia flash 8, Camtasia studio, Maouse pen.
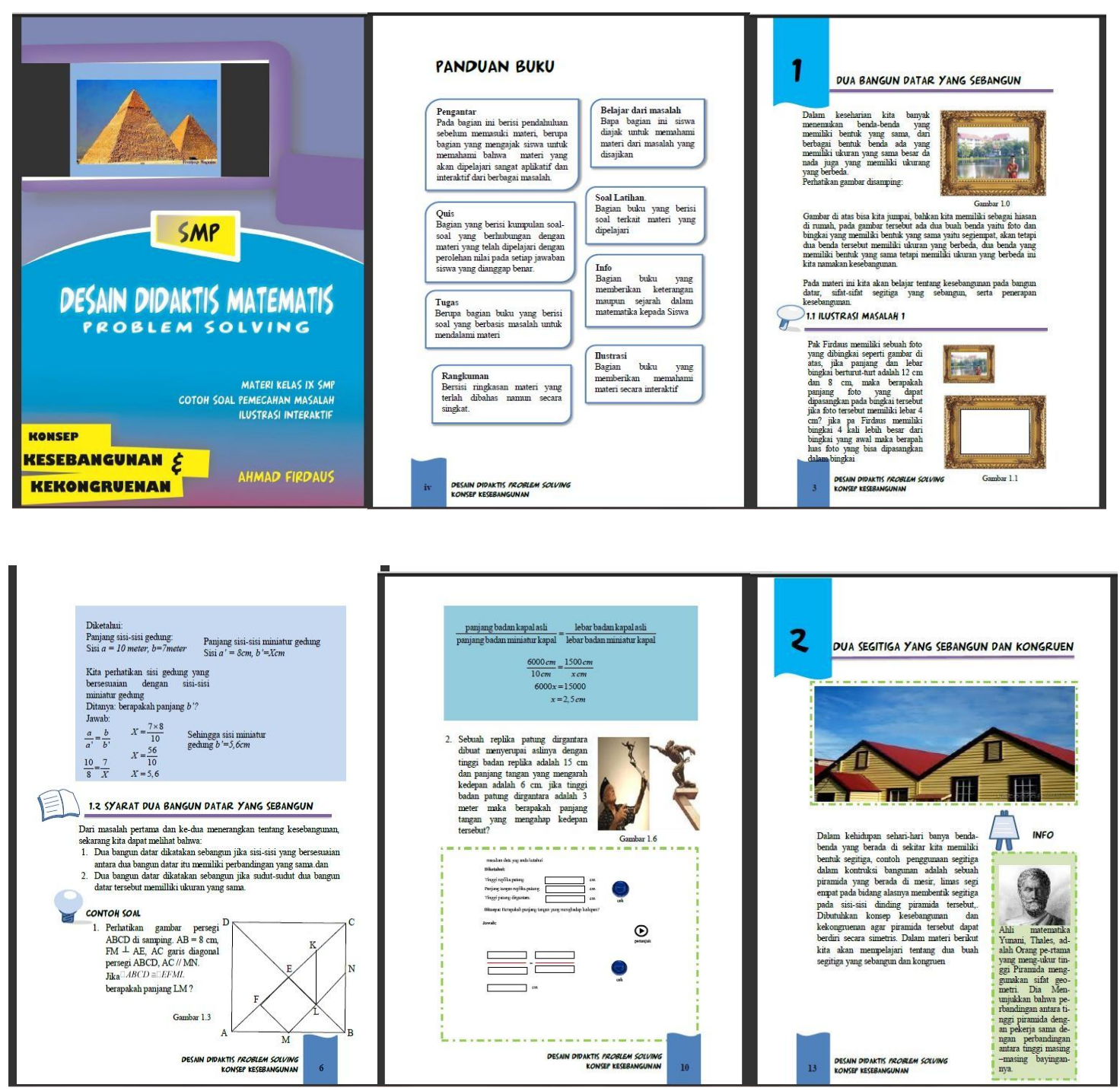

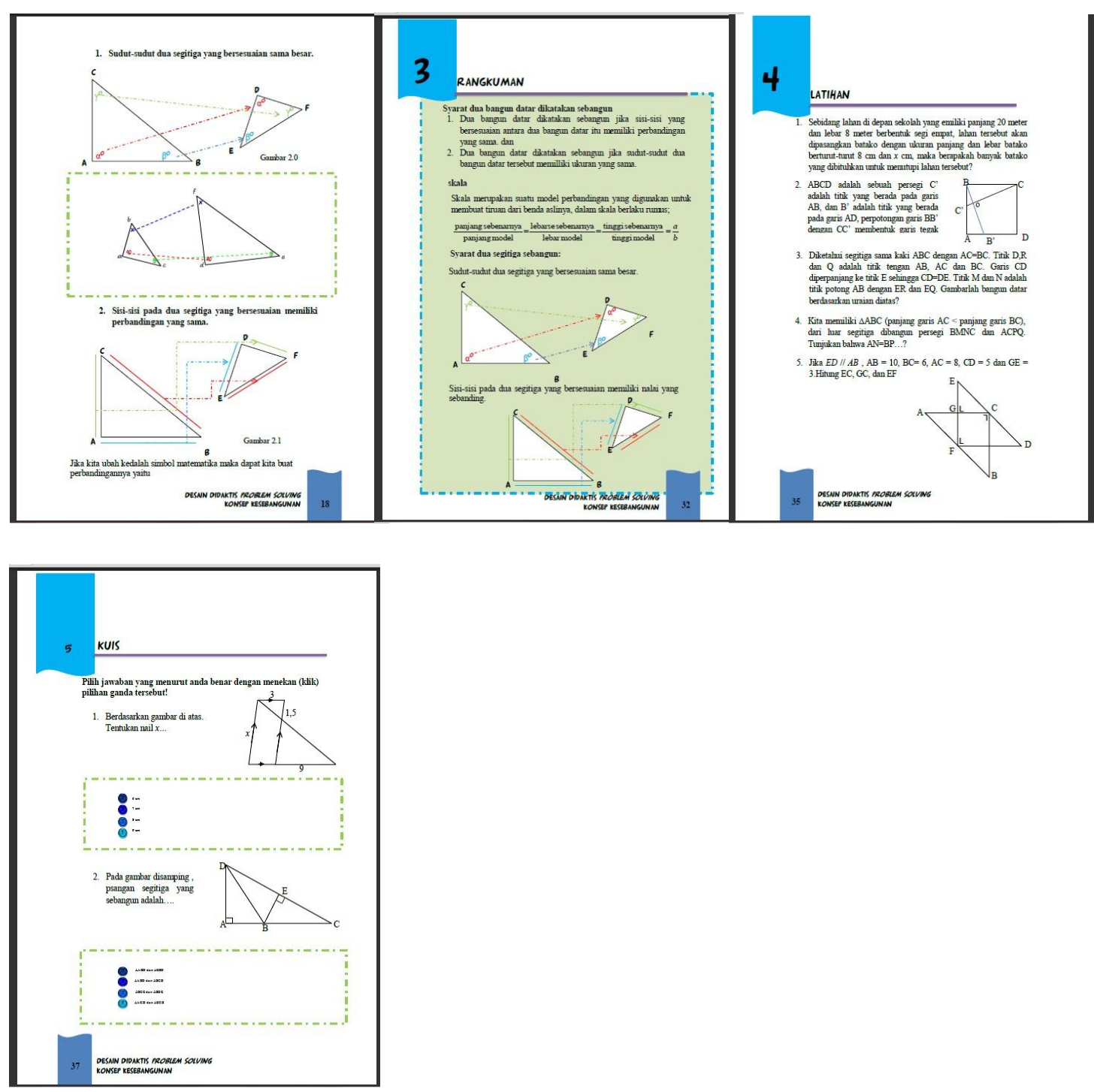

Gambar 2. Bahan ajar hasil analisis desain didaktis

\section{Hasil Uji Ahli}

Sebelum desain didaktis diujikan dalam skala kecil, maka dilakukan validasi terlebih dahulu. Validasi yang dilakukan meliputi tampilan, keterbacaan, kesesuaian materi, dan kesesuaian dengan learning obstacle yang diperoleh. Desain didaktis matematis problem solving awal diuji oleh bebeapa ahli, yaitu Ahli Pendidikan dan Ahli Matematika.

Penilaian uji ahli matematika dilakuan oleh dosen matematika Universitas Sultan Ageng Tirtayasa yaitu Dr. Syamsuri, M.Si. Adapun hasil penilaian uji ahli matematika berdasarkan aspek yang telah ditentukan tersebut, maka didapat skor penilaian oleh ahli matematika yaitu $61,54 \%$, maka secara keseluruhan konsep pemecahan masalah matematika desain didaktis awal yang telah dibuat dapat dikategorikan cukup baik untuk diimplementasikan ke dalam pembelajaran kelas. Untuk mendapatkan penilaian terkait konsep pendidikan dalam pemecahan masalah pada desain didaktis yang sudah dibuat, maka perlu adanya penilaian oleh ahli pendidikan. Penilaian uji ahli pendidikan dilakuan oleh guru matematika SMP 
N 7 Kota Serang yaitu Titing Skarningsih, S.Pd. Adapun hasil penilaian uji ahli pendidikan berdasarkan aspek penilaian yang telah ditentukan tersebut, maka didapat skor penilain uji ahli pendidikan yaitu $80 \%$, maka secara keseluruhan konsep pendidikan dalam pemecahan masalah pada desain didaktis awal yang telah dibuat dapat dikategorikan baik untuk diimplementasikan ke dalam pembelajaran kelas.

\section{Implementasi Desain Didaktis}

Implementasi atau pembelajaran menggunakan desain didaktis matematis problem solving pada konsep kesebangunan dilakukan di SMP N 7 Kota Serang dengan melibatkan 37 siswa kelas IX. Sample subjek implementasi yaitu siswa kelas IX yang belum mendapatkan materi kesebangunan dan kekongruenan, pada tahap implementasi ini peneliti melakukan observasi terhadap seluruh respon yang terjadi saat pembelajaran berlangsung.

\section{Respon siswa terhadap desain didaktis matematis problem solving pada konsep kesebangunan}

Dari hasil penyebaran angket tertutup kepada siswa setelah implementasi selesai dilakukan, maka rata-rata presentase respon tiap pernyataan yang diberikan oleh siswa terhadap desain didaktis matematis problem solving adalah $81.15 \%$, persentase tersebut menunjukan bahawa desain didaktis dalam kategori kuat, sehingga secara keseluruhan desain didaktis matematis problem solving konsep kesebangunan ini dinyatakan sangat baik.

\section{Learning obstacle yang tereduksi setelah implementasi desain didaktis matematis problem solving pada konsep kesebangunan.}

Berdasarkan hasil implementasi pada siswa berupa peningkatan kognitif dengan melalui perhitungaan gain ternormalisasi, maka analisis learning obstacle yanag tereduksi setelah implementasi adalah sebagai berikut:

a. Learning obstacle tipe 1 yaitu siswa tidak dapat membuat sketsa dan memanipulasi sktesa atau gambar.

Kesulitan belajar tipe 1 tersebut terjadi pada siswa ketika mengerjakan soal nomor 5, Berdasarkan hasil implementasi terdapat peningkatan kognitif siswa dalam mengerjakan soal nomor 5 yaitu $65.68 \%$. Hal ini menunjukan bahwa learning obstacle tipe 1 dapat tereduksi setelah melakukan pembelajaran dengan menggunakan desain didaktis.

Desain didaktis yang dibuat untuk mengatasi learning obstacle ini berupa ragam contoh soal yang memberikan bentuk-bentuk gambar atau sketsa, dan dimuat dalam animasi dalam computer sehingga siswa lebih memahami bagaimana gambar dapat dimanipulasi atau diatur sesuai kebutuhan. Melalui media ini diharapkan siswa dapat menuntaskan materi lebih singkat, hal ini sejalan dengan homsyer dalam noor 2004: 1 (Kusumah: 2010) dalam studinya telah menemukan bahwa siswa yang menggunakan komputer mampu menyelesaikan pelajaran rata-rata dalam 13,75 jam, sedangkan siswa yang mendapatkan pelajaran lewat tatap muka memerlukan waktu rata-rata 24 jam. Hal ini menunjukan penggunaan komputer mempengaruhi waktu pembelejaran. 
b. Learning obstacle tipe 2 yaitu siswa tidak dapat menentukan data yang diperlukan untuk menyelesaiakaan masalah.

Kesulitan belajar tipe 2 dapat dilihat saat siswa mengerjakan soal nomor 2 dan 4. Berdasarkan hasil implementasi terdapat peningkatan kognitif siswa dalam mengerjakan soal nomor 2 dan 4 , yaitu $64.59 \%$ pada peningkatan kognitif pengerjaan soal nomor 2 dan $70.81 \%$ pada peningkatan kognitif pengerjaan soal nomor 4 . Hal ini menunjukan bahwa learning obstacle tipe 2 dapat tereduksi setelah melakukan pembelajaran dengan menggunakan desain didaktis.

Desain didaktis buat untuk mengatasi learning obstacle ini berupa ragam soal dengan penyelesaian terbimbing, dimana siswa diajak secara interaktif untuk menyelesaiak masalah yang terdapat pada soal secara terbimbing, hal ini sejalan oleh pendapat Wahyudin (2010: 7) bahwa "pengembangan daya ingat yang baik untuk masalah-masalah serta pengalaman dengan beraneka ragam struktur masalah akan membantu siswa dalam menyelesaiakan masalah". Sejalan dengan pendapat Polya (Wahyudin: 2010) menganjurkan meodemetode heuristic salah satunya adalah pahami masalah. Apakah yang tidak diketahui? Apakah datanya? Apakah kondisinya? Hal ini sangat membantu siswa dalam mencari data yang diperlukan, karena siswa terlebih dahulu memahami masalah pada soal. sejalan dengan pendapat Glass (Kususmah: 2010) teknik bahan ajar bercirikan penemuan dapat dimanfaatkan untuk melatih siswa menetukan pola bilangan, rumus umum dari suatu barisan atau pola.

c. Learning obstacle tipe 3 yaitu siswa tidak dapat menetukan sisi-sisi yang bersesuaian.

Kesulitan belajar tipe 3 dapat dilihat saat siswa mengerjakan soal nomor 3 dan 6. Berdasarkan hasil implementasi terdapat peningkatan kognitif siswa dalam mengerjakan soal nomor 3 dan 6 , yaitu $61.35 \%$ pada peningkatan kognitif pengerjaan soal nomor 3 dan $69.19 \%$ pada peningkatan kognitif pengerjaan soal nomor 6 . Hal ini menunjukan bahwa learning obstacle tipe 3 dapat tereduksi setelah melakukan pembelajaran dengan menggunakan desain didaktis.

Desain didaktis yang dibuat untuk mengatasi learning obstacle ini berupa beragam contoh-contoh soal yang dilengkapi animasi, ilustrasi serta simulasi yang membantu siswa untuk memahaminya. Keanekaragaman dan pengontrasan yang ada pada simulasi yang disajikan dimana terdapat unsur membandingkan sisi-sisi yang bersesuaian ternyata mampu mereduksi learning obstacle yang serupa. Hal ini sesuai dengan dalil pengontrasan dan keanekaragaman yang dimukakan oleh Bruner (Suherman, 2003) bahwa pengontrasan dan keanekaragaman sangat penting dalam melakukan pengubahan konsep agar anak dapat memahami secara mendalam.

Keanekaragaman juga membantu anak dalam memahami konsep yang disajikan karena dapat memberikan belajar bermakna bagi anak. Sejalan dengan teori Arsyad (Asyhar, 2012: 53) yang menyatakan symbol pesan visual hendaknya memiliki prinsip kesederhanaan, keterpaduan dan penekanan. Kesederhanaan secara umum mengacu kepada sejumlah elemen yang terkandung dalam suatu visual. Jumlah elemen yang lebih sedikit memudahkan peserta didik menangkap dan memahami pesan yang disajikan 
visual itu. Jika ada pesan atau informasi yang panjang dan rumit maka dibagi kedalam beberapa bahan visual. Kemudian perlu penekanan dengan menggunakan ukuran, hubungan, perspektif, warna atau ruang penerangan dapat diberikan unsur penting. Dan keterpaduan yang mengacu kepada hubungan di antara elemen-elemen visual yang ketika diamati akan berfungsi bersama-sama. Elemen-elemen tersebut harus saling terkait dan menyatu sebagai suatu keseluruhan yang dapat dikenal dan dapat membantu pemahaman pesan dan informasi yang dikandungnya. berdasarkan teori tersebut maka dibuatlah desain animasi yang memunginkan siswa untuk belajar secara interaktif dalam menentukan sisi-sisi yang bersesuaian.

d. Learning obstacle tipe 4 yaitu siswa tidak dapat mengkonfersi soal cerita pada konsep kesebangunan dan kekongruenan.

Kesulitan belajar tipe 4 dapat dilihat saat siswa mengerjakan soal nomor 1 . Berdasarkan hasil implementasi terdapat peningkatan kognitif siswa dalam mengerjakan soal nomor 1 yaitu $65.68 \%$. Hal ini menunjukan bahwa learning obstacle tipe 4 dapat tereduksi setelah melakukan pembelajaran dengan menggunakan desain didaktis.

Desain didaktis yang dibuat untuk mengatasi learning obstacle ini berupa penyajian ilustrasi masalah realistis yang dilengkapi dengan audio-visual sehingga dapat membantu siswa dalam memahami masalah serta bagaimana mengkonfersi soal cerita tersebut kedalam penyelesaian dengan konsep kesebangunan dan kekongruenan.

\section{Kognitif siswa setelah implementasi desain didaktis}

Berdasarkan hasil kogitif siswa setelah implementasi desain didaktis dapam pembelajaran, maka terdapat peningkatan kognitif sebesar 0.83 , proses pembelajaran dengan menggunakan desain didaktis membrikan kesempatan siswa untuk belajar secara inraktif dan terstuktur. Jeromer Bruner (JICA UPI: 2001) dalam teorinya menyatakan bahwa belajar matematika akan berhasil jika proses pengajaran kepada konsep konsep dan struktur-struktur yang terbuat dalam pokok bahasan yang diajarkan.

Desain didakts yang dirancang menggunakan softwere serta animasi membuat kemampuan berpikir kritis siswa menngkat, sejalan dengan Stiadi (Kusumah: 2010) pembelajaran dengan bahan ajar interaktif berbasis komputer memberikan peningkatan kemampuan siswa dalam kemampuan berpikir kritis secara signifikan. Peningkatan kognitif siswa juga tak lepas dari pembelajaran yang dilakukan siswa dengan melakukan penemuan melalui soal tebimbing membuat siswa dapat menentukan rumus umum dari sauatu pola, sejalan dengan pendapat Glass (Kususmah: 2010) teknik bahan ajar bercirikan penemuan dapat dimanfaatkan untuk melatih siswa menetukan pola bilangan, rumus umum dari suatu barisan atau pola.

\section{SIMPULAN DAN SARAN}

Berdasarkan hasil dan pembahasan dari penelitian, maka dapat disimpulkan sebagai berikut: Learning obstacle yang ditemukan pada konsep kesebangunan dan kekongruenan dibagi menjadi empat tipe, yaitu:

a. Tipe 1: Siswa tidak bisa membuat sketsa dan memanipulasi sketsa dengan benar. 
b. Tipe 2: Siswa tidak dapat menentukan data yang diperlukan dalam menjawab soal.

c. Tipe 3: Siswa tidak dapat menentukan sisi-sisi yang bersesuaian pada objek yang sebangun dan kongruen.

d. Tipe 4: Siswa tidak dapat mengkonfersi soal cerita kepada konsep kesebangunan yang akan diselesaikan

Berdasarkan rata-rata nilai pretes sebesar 19.19 dan dan rata-rata nilai postes 86.35 , maka didapat gain sebesar 0.83 , sehingga dapat disimpulkan bahwa terdapat peningkatan kognitif pada siswa setelah melakukan pembelajaran dengan menggunakan desain didaktis matematis problem solving pada konsep kesebangunan.

Berdasarkan hasil penelitian ini, direkomendasikan bahwa bahan ajar dengan desain didaktis matematis yang disusun berdasarkan repersonalisasi dapat diterapkan pada konsep kesebangunan dan diharapkan dapat mengantisipasi lerning obstacle pada siswa, sehingga siswa tidak mengalami kesulitan dalam belajar. Isi dari desain didaktis tersebut meliputi ilustrasi masalah, materi, simulasi interaktif, soal terbimbing, rangkuman, latihan dan kuis.

\section{DAFTAR RUJUKAN}

Adri, M dan Azhar, N. (2008). Pengembangan Paket Multimedia Interaktif sebagai Sarana Belajar Mandiri Mahasiswa. (Online). (http://ilmukomputer.org/wp-content/uploads/2008/03/adri_nelda_ makasemnas2008.pdf diakses 27 November 2012).

Agustina, N. (2012). Desain Didaktis Pembelajaran Matematika SMP pada Pokok Bahasan Kubus. Skripsi Pendidikan Matematika UPI Bandung: (http://repository.upi.edu/skripsiview.php?no_skripsi=13249 diakses 10 Juli 2013).

Arsyad, Azhar. 2005. Media Pembelajaran. Jakarta: Raja Grafindo Persada.

Asep, dkk. 2012. Pengembangan Bahan Ajar. (Online). (http://file.upi.edu/direktori/fip/jur.kurikulum_dan_tek.pendidikan/1946012 91981012 permasih/pengembangan_bahan_ajar.pdf. diakses 27 november 2012).

Gordah, Eka Kasah. (2009). Meningkatkan Kemampuan Koneksi dan Pemecahan Masalah Matematik melalui pendekatan Open Ended. Tidak diterbitkan. Tesis Magister pada FPMIPA UPI Bandung.

Hoesana, Jhonathan. (2012). Sukses juara olimpiade matematika. Jakarta: Grasindo.

Irawan, Adilia.(2011).Desain Didaktis Bahan Ajar Problem Solving Pada Konsep Persamaan Linear Satu Variabel. UPI Bandung: Tidak diterbitkan

Kesumawati, Nila. (2010). Peningkatan Kemampuan Pemahaman, Pemecahan Masalah, dan Disposisi Matematis Siswa SMP melalui Pendekatan Pendidikan Matematika Realistik. Tidak diterbitkan. Disertasi pada Sekolah Program Pasca Sarjana UPI Bandung.

Kusumah, Yaya. (2010). Model Pembelajaran Matematika Berbasis Teknologi Informasi Untuk Siswa Sekolah Menengah. Teori, Paradigma, Prinsip, dan Pendekatan Pembelajaran MIPA dalam Konteks Indonesia. Bandung: JICA FMIPA Universitas Pendidikan Indonesia. 
Organisation for Economic Co-operation and Development. (2010). PISA 2009: Science Competencies for Tomorrow's World, Executive Summary. (Online). (http://www.oecd.org diakses 12 Juli 2012)

Sarwiko, Dwi. (2010). Pengembangan Media Pembelajaran Berbasis Multimedia Interaktif Menggunakan Macromedia Director MX (Studi Kasus Mata Kuliah Pengolahan Citra pada Jurusan S1 Sistem Informasi). (Online). (http://www.gunadarma.ac.id/library/articles/graduate/computerscience/201 0/Artikel_10105507.pdf.27 November 2012)

Setiyono, Bambang Dwi. (2008). Pengembangan Pembelajaran dengan Menggunakan Multimedia Interaktif untuk Pembelajaran yang berkualitas. Karya Tulis Ilmiah pada FIP Unnes. (Online). (http://etraining.tkplb.org/file.php/1/moddata/data/3/9/31/pengembangan pembelajaran dengan menggu.pdf .27 november 2012)

Sugiyono.(2009).metode penelitian kuantitatiif, kualitatiif, dan $R \& D$. Bandung: Alfabeta.

Sugiyono. (2011). Metode Penelitian Pendidikan: Pendekatan Kuantitatif, Kualitatif, dan R\&D. Bandung: Alfabeta CV.

Sulistiawati. (2012). Pengembangan Desain Didaktis Bahan Ajar Penalaran Matematis pada Materi Luas dan Volume Limas. UPI Bandung: Tidak diterbitkan.

Suryadi, Didi. (2010). Metapedadidaktik dan Didaktical Design Research (DDR): Sintesis Hasil Pemikiran Berdasarkan lesson study. Bandung: FPMIPA UPI

Suryadi, Didi. (2008). Metapedadidaktik dalam Pembelajaran Matematika: Suatu Strategi Pengembangan Diri menuju Guru Matematika Profesional. Pidato Guru Besar di Universitas Pendidikan Indonesia, Bandung.

Sutame, Ketut dkk. (2012). mereduksi mathematics anxiety dan menyuburkan problem solving ability dengan pendekatan problem posing. Tidak diterbitkan. (Online). (http://eprints.uny.ac.id/8096/ 30 mei 2019)

Tim MKPBM jurusan pendidikan matematika. (2001). strategi pembelajaran matematika kontemporer. Bandung: JICA UPI.

Turmudi. (2010). Pembelajaran Matematika: Kini dan Kecenderungan Masa Mendatang. Pembelajaran MIPA dalam Konteks Indonesia. Bandung: FPMIPA UPI.

Wahyudin. (2010). Peranan Problem Solving dalam Matematika. Pembelajaran MIPA dalam Konteks Indonesia. Bandung: JICA FPMIPA UPI.

Wardhani, I. (2006). Efektivitas Penggunaan Komputer dalam Pembelajaran Matematika Interaktif Model Tutorial untuk Meningkatkan Kemampuan Berpikir kritis dan Motivasi Belajar Matematika Siswa SMA. Tidak diterbitkan. Skripsi Universitas Pendidikan Indonesia. 